ALFRED STIEGLITZ 


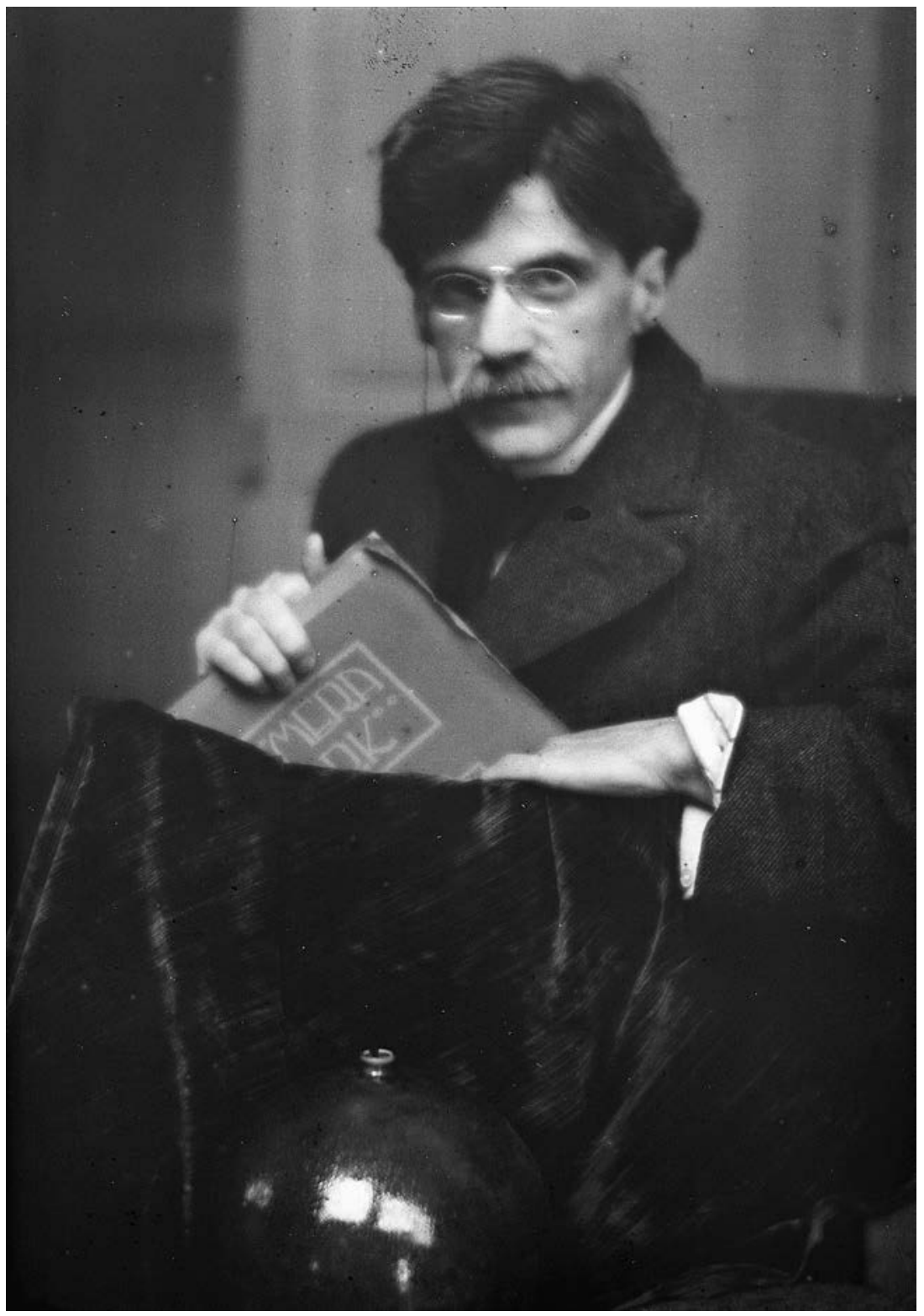




\section{Alfred Stieglitz}

\section{Taking Pictures, \\ Making Painters}

PHYLLIS ROSE

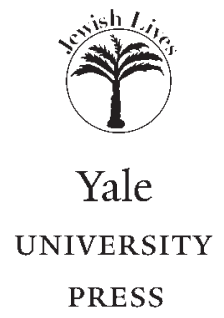

New Haven and London 
Copyright (C) 2019 by Phyllis Rose.

All rights reserved.

This book may not be reproduced, in whole or in part, including illustrations, in any form (beyond that copying permitted by Sections I07 and Io8 of the U.S. Copyright Law and except by reviewers for the public press), without written permission from the publishers.

Yale University Press books may be purchased in quantity for educational, business, or promotional use. For information, please e-mail sales.press@yale.edu (U.S. office) or sales@yaleup.co.uk (U.K. office).

Frontispiece: Edward Steichen, Alfred Stieglitz, 1907. (Alfred Stieglitz Collection, 1955. Image copyright (C) The Metropolitan Museum of Art.

Image source: Art Resource, NY. (C) 2018 Estate of Edward Steichen/Artists Rights Society [ARS], NY.)

Picture Research by Laurie Platt Winfrey, Carousel Research.

Set in Janson OldStyle type by Integrated Publishing Solutions. Printed in the United States of America.

Library of Congress Control Number: 2018955013

ISBN 978-0-300-22648-5 (hardcover : alk. paper)

A catalogue record for this book is available from the British Library.

This paper meets the requirements of ANSI/NISO Z Z39.48-I992

(Permanence of Paper).

I0 $9 \begin{array}{llllllll}8 & 7 & 6 & 5 & 4 & 3 & 2 & \text { I }\end{array}$ 
To Mary Ryan, art dealer, and to David Schorr, artist and educator 
This page intentionally left blank 